\title{
Polish political humour. An outline of the phenomenon
}

\author{
Marcin Poprawa
}

\begin{abstract}
This article is a survey of the most important communicative phenomena in the contemporary Polish political humour. It is also an attempt to describe political humour from a theoretical point of view and to compare it with political jokes from a period of the Polish People's Republic (PRL). This article mainly describes amusing statements of contemporary politicians that were primarily used as the means of a political polemic, and secondarily after having been popularised by journalists (due to their comic content), achieved a status of "winged words" and appeared in various intertextual variants of the public and colloquial discourse.
\end{abstract}

Keywords: Polish political humour, intertextuality, winged words, political discourse, language of politics

\section{Background}

In this article I will outline the most important communicative aspects in contemporary Polish political humour. It is also an attempt to give a theoretical account of this communicative phenomenon and to compare it with political jokes from the Polish People's Republic (PRL) and communist party propaganda from this period. I will present examples of statements uttered by Polish politicians that were primarily used in political discussion and secondarily (due to their comic content) were popularised by journalists, achieving a status of "winged words". Consequently the statements made appearance in intertextual humour in public and colloquial discourse. 


\section{Political humour - description of the phenomenon}

Irrespective of the fact that the term "political humour" refers to funny situations and images related to politics, it is more frequently present in areas of social communication other than the political discourse (contemporarily mainly in print / broadcast media and the Internet). Most frequently it evolves in the form of jokes, i.e. short verbal narrative forms ending with a punch line ${ }^{1}$, or in the form of satirical verbal and non-verbal genres that accompany political commentary, or comic sketches ridiculing the blunders of politicians ruling the country: their decisions, behaviour or attitudes.

Politics is the sphere of social life that should be least likely associated with fun. However, contemporary cultural transformations have led to the situation where the language of politics reaches a larger audience using the form of simple, vivid and emotive statements rather than sophisticated oratorical shows. Consequently, one can find among ritualised forms of political discourse (such as election campaigns, political advertisements) ludic means of persuasion related to various emotions (from joy to indignation - see: Brzozowska 2009c). Emotive examples of Zwizschenruf ('shouts in-between'), ie random ironical comments, are treated by some people as situation-based jokes, whereas others regard them as slips of the tongue lowering the standards of official communication. The use of such communicative means usually accompanies both parliamentary debates and TV discussions hosted by journalists (see: Poprawa 2009; SzkudlarekŚmiechowicz 2011; Kloch 2006 and others). Researchers generally agree that contemporary political discourse changes together with patterns popularised by mass media, thus the "spirit of fun" (Magdon 1995), carnivalisation of the language of politics (among others Ożóg 2004) and last but not least the ludic element present in election advertisements and campaigns (e.g. satirical video clips, pastiches based on cartoons and photographs, used by politicians for the purpose of attacking their opponents) are not regarded as strange. Such communicative strategies treated as options for political marketing accompany rational debates and are referred to as "political folklore" (see: Kamińska-Szmaj 2001) or "pop entertainment and pop persuasion" (Olczyk 2010). The latter notion refers to an entire set of communicative strategies and genres which try to influence the audience with incongruous meanings and connotations both in pictorial and verbal form.

The common sense perception of jokes and humorous narratives or pictures categorises these as belonging to colloquial speech or verbal art rather than to official public discourse. Nevertheless, ludic forms (and especially satire)

1 For an overview of researchers and articles in the area of "ludic genology", see the article by Brzozowska (2010). 
have accompanied the rhetorical style and public speeches ever since ancient times and have been used in order to comment on events, issues and people (see Korolko 1998)2. Politicians scoffed at their opponents in their speeches, often making use of invective (so called invectiva oratio - see Kamińska-Szmaj 2007) or irony (see Habrajska 1994). Funny rhetorical figures often accompanied public communication as a way of attracting and activating listeners. It was also a means of sharp criticism towards an opponent and his/her achievements. The classic speeches of renowned rhetorical masters (among others Demosthenes, Aristophanes and Archilochus of Paros - more about this in the work by Kamińska-Szmaj 2007) and people highly valued by political elites of their times ${ }^{3}$ repeatedly use fragments full of virulent humour.

Polish political satire was popular at the time when Polish political elite was more active (e.g. in the $16^{\text {th }}$ century, the period of humanism, the so called "golden age of noble democracy"; or the end of the $18^{\text {th }}$ century - the Enlightenment, the period when social and political topics were dominant in literature and culture). Satire often used examples from ancient times, popularising not only literary and rhetorical forms of Demosthenes, Lucan, Horace, but also promoting the genre forms created and developed in the period of humanism by Erasmus of Rotterdam and later by Voltaire (cf Stownik terminów literack$i c h$ 1998). This way of addressing topical issues appeared in various areas of public life and it was further popularised through the $17^{\text {th }}$-century political comedy (known by the works by Julian Ursyn Niemcewicz in Poland). The aim of political mockery was to point at the misdemeanours of citizens and governing politicians in order to educate through laughter, but it also functioned as a tool for political power struggle among political groups and intellectual elites.

Political humour appears in various kinds of discourse (such as colloquial / media / political discourses) and is represented by a number of genres (e.g. joke, other humorous verbal formats, literary humour, pictorial (drawn / photographbased) satire) and artistic forms (e.g. cabaret, talk-show). Similarly, it has various communicative auditoriums (e.g. in the real world, on the Internet). Its multifaceted nature makes up one of the reasons that render the description of this communicative phenomenon difficult. The other reason refers to communicative intentions included in numerous jokes or comical texts, as a lot of them are used to deride and revile an ideological opponent. They show virulent laughter and lexical means considered unethical or vulgar in their verbal content.

${ }^{2}$ Compare comments on irony and sarcasm as figures of speech used in ancient public speeches.

3 See interesting comments on comical content of Józef Piłsudski's speeches in the article by M. Dawidziak-Kładoczna (2006). 
According to Dorota Brzozowska (2009c: 155), ludic / comical discourse penetrates all other communicative universes; it is a "type of a 'communicative event' in which the inclination for fun becomes an idea that is passed on [...], and the aim of the interaction is to create a "community of laughter"".

In the light of those assumptions, political humour could be defined as a set of verbal and non-verbal forms of behaviour arising from the interaction of two discursive spheres, a public and a ludic one; it is a contamination of their communicative categories. A necessary condition in order to launch a humorous meaning is to combine, at the very least, the following prerequisites:

- at the mental level - an evaluative, comical and language-related image of politics (of politicians and situations connected with them) must be included;

- at the pragmalinguistic level - the intention to show politics in a distorting mirror must be expressed, i.e. there is a wish to talk about politics in order to 1) make somebody laugh (to elicit laughter / approval in people who think about the situation in a similar way); 2) to ridicule something / someone (so as to demean representatives of political authority or somebody's way of thinking about politics / interpreting politics).

The difficulty to classify style- and genre-based types of political humour arises from the overall status of contemporary language, especially the language of politics and media (see: Kamińska-Szmaj 2001; Wojtak 2010). Public statements are subordinated to official style only from a situation-related point of view. They are usually characterised as being full of freedom and creativity, in which (quasi) figures of speech may be collated with vivid (e.g. colloquial and funny) lexical forms (cf Kudra 2001), and the feeling of seriousness is confronted with humorous emotive speech acts.

There are lots of participants and communicators in this area of public discourse. Currently, in the Polish political discourse, humour may be used by various speech communities and in various pragmatic situations. Most frequent of these include:

- politicians' talk about other politicians - humour functions here as a way to ridicule the opponent and fight for political power; it is used in order to diminish the importance of an adversary (in the eyes of governing politicians or citizens);

- media commentary on public persons and political events - the ludic atmosphere accompanying such statements (e.g. as news texts or political comments) is used in a form of political satire or "ridiculing voices" (Wojtak 2010). The essence of this form, media entertainment intertwined with politics, may be seen in the old press cartoons ${ }^{4}$. Nowadays, the

4 One of the most popular satirical periodicals about politics was the pre-war "Mucha" ('Fly'); in a period of PRL its visual traditions were continued by "Szpilki" ('Pins'), a magazine "rationed" by political authorities. 
equivalent is the pastiche of comic strips, photo essays and video clips which usually comment on the main issues of news bulletins ${ }^{5}$, which are themselves created as of infotainment;

- citizens talk about politicians (and politics) - this is the least stable and most diverse axis of political discourse as it refers to images and opinions about politics that are shared by various communities which frequently express ideological beliefs and liking / antipathy towards various political actors. The competence of people disseminating or creating this kind of humour (more actively on the Internet than in face to face communication) depends on their ideological identity and the sense of belonging to a community.

The above division could also include ironical self-representation - i.e. communicative strategies which politicians use to talk about themselves in a funny way. It is not a common behaviour, but increasingly used by some politicians as an element of communicative play or as a new custom in the political etiquette.

Contemporary political jokes are varied at the level of both content and style. They can be properly understood by people sharing not only the same sense of humour, sensitivity and the ability to understand similar associations and word games, but also sharing the same axiological system. This refers mainly to statements by the representatives of main political parties or to jokes about them. There is a frequent clash of opinions, which is especially reflected in the jokes collected in the press or from Internet portals. The jokes show a polarisation of Polish ideological identities.

In an attempt to define contemporary political humour, one should also refer to the theory of discourse. In the interactive approach to this methodology (created by Michael Halliday and John Firth, and completed by Teun A. van Dijk 2001), the following metafunctions are established: mental, interpersonal (interactive), and textual / textual-stylistic. While referring to the concept of ordering relationships between the ludic discourse sensu largo and areas of its impact on other communicative spheres (suggested by Brzozowska 2009c), political humour performs among others the following functions:

1. Mental level - telling political jokes and humorous stories about the world of politics expresses the axiological and ideological identity of speech communities. It is tied to the fact that jokes reflect discursive symbols and numerous colloquial conceptualisations of political reality that display images, attitudes and evaluations (approved / disapproved) of political events at the level of colloquial narrations. Those attitudes may be conveyed as a series

5 The best examples are tongue-in-cheek comments in the closing parts of Teleexpres (TVP 1) or Fakty (TVN), which are popular news programs. 
of jokes, e.g. in the case of jokes based on the opposition between Tusk and Kaczyński, which in their intertextual forms refer to real divisions between those two parties (PO-PiS) on the political scene.

2. Interactive / pragmalinguistical level - humorous statements related to political authorities may be expressed by politicians, journalists and speech communities in order to: a) elicit laughter among people with the same ideological identity and a similar sense of humour; b) discredit other politicians (or groups); c) criticise negative aspects of the public life;

3. Textual level - political humour is present in numerous situations and genres of the political communication: a) in formal circulation (e.g. media, Internet, reports from official political events); b) in closed, dispersed (or ephemeral) communicative circulations, such as verbal jokes and humorous statements in vivid colloquial language or carefully considered narrations on satirical Internet portals.

\section{Polish political humour in the period of PRL and today - an attempt at comparison}

Although political jokes in PRL circulated inside closed communities, they may serve as an example of the most versatile and varied joke culture in comparison to the contemporary Polish ludic tradition both on the Internet and in the oral lore. This is because jokes expressed the collective identity of the Polish society with regard to the opinion about the political situation which was in contrast to the totalitarian propaganda; they exposed the shortages and absurdities of the surrounding social reality; and last but not least they were the expression of forbidden social or ideological attitudes that did not fit the official discourse.

Forbidden political humour, circulating in oral interaction, was popular not only due to its inherent allusions to overturning the dominant ideology that was maintained by political authorities, tightly subordinated to them, and disseminated by monotonous propaganda in public communication (see Głowiński 1992; Bralczyk 2001; Kamińska-Szmaj 2007; Dytman-Stasieńko 2006 and others). Above all, it was popular due to the fact that it made use of taboo topics. It overturned the communist party's communicational monopoly, replacing it with "ludic political comments" available exclusively in day-to-day unofficial communicative situations (see also Rebane 2012). 
The value of this aspect of informal communication is marked by extremely rich collections of oral narrative forms, some of which, irrespective of changed reality, still evoke social resonance and are willingly adapted to present-day needs also on contemporary Internet portals.

According to researchers, Polish socialist jokes shared the same fate as jokes known in other European countries controlled and influenced by the USSR (cf Davies 2009; Brzozowska 2009a; 2009b and others). Socialist jokelore was characterised by rich narratives ridiculing the representatives of political authorities and communist party apparatus (e.g. Brezhnev, Gierek, Gomułka, Jaruzelski), common topoi showing the absurdities of life under the influence of a socialist doctrine (e.g. jokes about inventions of Soviet "scientists", about propaganda broadcasts by Radio Yerevan), and finally, interpretations of current geopolitical situation of countries "from behind the iron curtain" (e.g. "friendly working visits" of communist leaders in their own circle or their diplomatic meetings at the summit with leaders from countries outside the Eastern Bloc - e.g. series of jokes about Reagan and Gorbachev).

All those genres were confronted with pushy and monotonous communist party propaganda that tried to force humour into the subordination of the political doctrine and was rather derisive about its significance. As far as examples of official political jokes in the early PRL period are concerned, one can mention among others satirical drawings and posters serving the purpose of reviling political opponents (called ideological enemies) or acts of behaviour condemned or forbidden by the political party apparatus (e.g. posters ridiculing loafing, alcohol abuse of the whole nation, public enemy, where a directive form of appeals, bans and orders were collated with statements formulated in "educational" style such as "Be vigilant..."; "Don't neglect ..." etc.).

The regime expresses its propaganda among other things by posters full of virulent irony, advocating against listening to broadcasters "from behind the iron curtain" - Radio Free Europe and Radio BBC. In such graphic satire usually someone with low intellectual abilities and a comic appearance is depicted and attacked, and underlying negative associations accompany abusive labelling like "imperialist", "burgeois", "reactionary".

Frequently repeated figures of a banker or capitalist are the carriers of those meanings. On the other semantic pole, another figure related to Polish traumatic events from the Second World War can be found: visual metonymy of "illegal radio set" as a Nazi spittoon, barking loudspeaker (reference to German street loudspeakers through which the occupier distributed aggressive information unaccepted by the Polish people). In the midst of rising hostile attitudes and 
fear of Western information channels, "educational" rhymes attacked the figure of the capitalist - ad absurdum in their form and ad baculum in their content - like in the following example:

Stuchat, stuchat Bibisyna [radia BBC], aż mu spuchta tepetyna.

Dureń, co stucha [RWE] z mina tak błoga.

Komu pomaga? Śmiertelnym wrogom.

He listened to Bibisyn [radio BBC],

Until his head had swollen.

An idiot who listens to Radio Free Europe with such a blissful face.

Whom does he help? His mortal enemies.

(www.ipn.gov.pl)

Political humour in PRL was distinguished not only by its versatile form and rich variety of communicative scripts immersed in colloquial, oral circulation - its high level is also reflected in other comic genres (mainly cabaret sketches and numerous satiric and entertaining programmes) popularised by artistic elites. Of course, ludic content related to social and political reality was subject to censorship; however, comedians managed to smuggle in allusive content against governing politicians in official communicative situations. Examples, among others, include cabaret evenings during the National Festival of Polish Song in Opole, "New Year puppet shows" televised usually after official New Year wishes by the first secretary of PZPR (Polish United Workers' Party), allusive dialogues from Kabaret Olgi Lipińskiej, Kabaret Starszych Panów (see Chłopicki 2012), series of radio entertainment programmes such as 60 minut na godzinę, $Z$ pamiętnika młodej lekarki etc.

Social and political transformations after 1989 changed political, public and media communication (cf. among others Kamińska-Szmaj 2001 and 2007; Bralczyk 2001; Bralczyk \& Mosiołek-Kłosińska 2001; Ożóg 2004; Anusiewicz \& Siciński 1994; and others), and influenced anonymous political folklore and political humour. The latter started to appear in official communicative discourse as a form of a commentary. As expressed by Irena Kamińska-Szmaj, "telling jokes in unofficial situations lost its attractiveness of the "forbidden fruit" [...] spontaneous and anonymous humorous works were replaced with the authors' comical evaluation of political events published in the form of jokes, short poems, feature articles or satirical cartoons" (2001: 189-190).

It is worth supplementing those conclusions with another comment: difference in quality between Polish political jokes in PRL (the "forbidden" / "whis- 
pered" jokes) and contemporary time ("political folklore”, "polit-entertainment”) can be seen first of all at the pragmalinguistic level, i.e. at the level of language behaviour of speech communities finding joy in showing politics in a distorted mirror and in reflecting on situation-related circumstances in which jokes are used. In other words, there is a discontinuity between telling jokes as a sign of joy arising from breaking a taboo in PRL vs. telling jokes as a sign of an intertextual game between communities sharing different political views.

The potential of jokes as a rich source of textual derivation as well as their aesthetic quality has changed. Political jokes from pre-1989 were characterised by distinctive and repeated components of colloquial textual elements (such as recognisable markers of textual delimitation, i.e. similar opening and closing (punch line) narrative structures; comprehensive axiological stereotypes for depicting heroes; stereotypical and clear-cut relations to political and historical realities - e.g. conventional three characters Pole, Russki and German, performing satire against Nazi occupiers, who were later replaced with joke adaptions presenting the realities of the Cold War, in the form of jokes about a Pole, Russki and American $)^{6}$. The content of contemporary political satire is less formalised and consequently penetrates everyday language to a lesser extent. Therefore it contains accidental narrations, bon mots, clusters of sayings appearing for a short time in colloquial circulation due to the popularity of TV shows (such as Szymon Majewski Show, Szkto kontaktowe), and Internet visual formats (photo blogs, cartoons and drawings, video clips or collections of so called demotivators; see also Baran 2012, and Piekot 2012). Recognisable repertoire of oral texts appears more rarely in colloquial circulation. In other words - verbal political humour (similarly to other forms of popular culture) has been subjected to media influence, globalisation and fragmentation. Success and accuracy of ludic elements in jokes is no longer based only on their allusive character but first of all on their range of influence in speech communities.

The comparison related to the analysis above is summarised in Table 1:

$\overline{6}$ Cf Brzozowska (2009a $; 2009$ b) on identity and stereotypes in ethnic jokes; see also Brzozowska 2012, and Krikmann 2012. 


\begin{tabular}{|c|c|}
\hline & $\begin{array}{l}\text { ONTEMPORARY } \\
\text { OLITICAL HUMOUR }\end{array}$ \\
\hline $\begin{array}{l}\text { forbidden in official political propa- } \\
\text { ganda (e.g. during official speeches } \\
\text { made by representatives of political } \\
\text { authorities), subject to censorship that } \\
\text { "rationed" allowed and arbitrarily se- } \\
\text { lected ludic content } \\
\text { forbidden in colloquial communication } \\
\text { (taking the shape of so called whis- } \\
\text { pered jokes) }\end{array}$ & $\begin{array}{l}\text { - free, unlimited, covering various com- } \\
\text { municative situations } \\
\text { appearing also in official communi- } \\
\text { cative situations (e.g. during parlia- } \\
\text { mentary debates, press conferences, } \\
\text { election meetings and politicians' ap- } \\
\text { pearances in media) }\end{array}$ \\
\hline $\begin{array}{l}\text { separate communicative chan- } \\
\text { rculations): } \\
\text { - "rationed" by political au- } \\
\text { es as derisive humour for the } \\
\text { e of providing ridiculing prop- } \\
\text { against a political opponent } \\
\text { ial - a real form of political hu- } \\
\text { a collection of jokes which ridi- } \\
\text { he regime, political authorities, } \\
\text { rty apparatus }\end{array}$ & \begin{tabular}{|ll}
- & In two overlap \\
channels (circul \\
1. & official-humour \\
& senders, popula \\
& sites and entert \\
& and also appear \\
& surprise during \\
2. & unofficial - freel \\
& day political con \\
ers belonging to & tive communiti \\
values and ideol
\end{tabular} \\
\hline $\begin{array}{l}\text { colloquial circula- } \\
\text { d by intellectuals } \\
\text { g. the role of a TV } \\
\text { f cabaret evenings } \\
\end{array}$ & $\begin{array}{l}\text { - funny } \\
\text { and art } \\
\text { to the u } \\
\text { without } \\
\text { tic elite } \\
\text { evening }\end{array}$ \\
\hline $\begin{array}{l}\text { f commonly known and un- } \\
\text { zes using repeated scripts } \\
\text { of the representatives of } \\
\text { thorities (mainly about } \\
\text { uzelski, Gomułka), partly } \\
\text { om the USSR from nar- } \\
\text { ut Brezhnev, Stalin, Gor- }\end{array}$ & 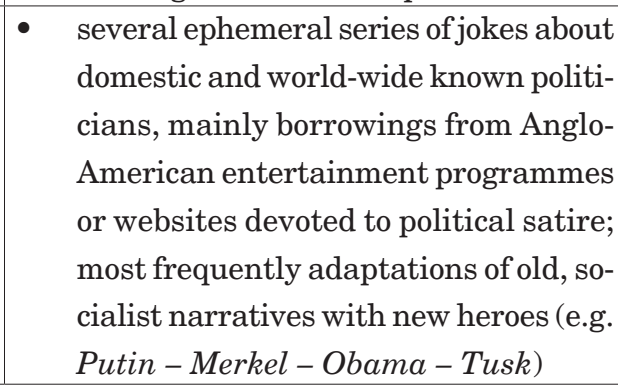 \\
\hline
\end{tabular}

Table 1. Comparison of political humour in PRL and present day. 


\section{Communicative and intertextual characteristics of political "winged words"}

In contemporary social communication (both colloquial and public), humorous texts are rarely passed on as oral political jokes (i.e. narrative forms with similar scripts, topoi and punch lines). Instead, they appear as quotations, phrasemes or paraphrases of politicians' speeches and due to the emotional content, surprising associations and evaluating allusions of the source material, they penetrate various spheres of discourse.

Unexpected events violating the seriousness of official communicative situations are most frequently a source of contemporary political humour. Gaffes in politicians' and diplomats' behaviour, slips of the tongue and awkward statements contrasted with the seriousness of a political discourse, or illogical statements violating rules of the official language, are very quickly picked up by journalists. These observations will then start their "ludic lives" in various intertextual contexts in media discourse and are later popularised by anonymous authors in various virtual communities. On the one hand, the "winged words", uttered by people representing the world of politics (see Chlebda 2005; Kita 2000), are used in order to vividly present difficult problems in an easy and understandable manner (e.g. terminology or interpretations related to political events), conceptualising associations with the communicative situation in which they appear. On the other hand, slips of the tongue made by public persons reach newspapers, entertainment programmes aimed at commenting on political matters as well as "virtual diaries of gaffes" in new intertextual forms with an intention to ridicule authors of those statements. Also, mock political commentary (see Wojtak 2010) is a form of popular political humour. This "visible or rather audible" (Kamińska-Szmaj 2001: 189) kind of humour accompanies parliament debates (vivid verbal and non-verbal reactions are carefully noted in stenographic records with a note cheerfulness in the hall), press conferences, interviews and journalists' talks with politicians in either official circumstances (e.g. TV studio) or unofficial ones (e.g. accidental journalists' interactions with politicians in the parliament corridors, telephone calls, etc.). Most of those texts are based on the mechanism of surprise (incongruence) ${ }^{7}$, so their humorous potential is based on quick decoding of verbal and non-verbal meanings and on comic situations accompanying official events.

Pragmatic features of situation-based verbal humour that appear in official political communication have been outlined by Irena Kamińska-Szmaj. Her

7 The incongruence in humorous texts and research on this communicative phenomenon (including references to classical theories by S. Attardo, V. Raskin, W. Ruch and others) is presented among others by Kucharski (2009). 
reseach is based on the humorous statements of Polish members of parliament. She specifies the following functions of humorous texts (2001: 131-132):

1. therapeutic (emotional) - laughter is the reaction to an unexpected situation where the ideas and thoughts about serious public discourse held by participants of political events are being contrasted (e.g. during parliament debates, press conferences). Laughter usually involves all the participants of the communicative event, as it is a non-verbal signal of decoding two mutually exclusive communicative scripts, and not initialised by negative emotions towards certain people;

2. integration oriented - a joke can be decoded similarly only by an auditorium belonging to the same "community of laughter" (in case of political actors, by people belonging to the same intellectual and ideological community). The feeling of joy is then shared by all of the community members who are motivated and able to decode the humour (primarily, its connotations) included in a statement that for other people sounds serious. This type of humour may be a sign of satisfaction for one group of people and a sign of indignation for another. Therefore it can be used in political polemics as one of the strategies of polarising the political scene between dichotomous (axiologically mutually exclusive) communities of "us" versus "them".

3. demoting - it is one of the most common tools used in political power struggle. The humorous meaning of a given statement (in the form of jokes or ironical verbal games) or the humorous script appearing in it is used to demean the target of the statement. A comic speech act thus turns into a mocking one. Derisive forms of laughter are frequently decoded in political discourse as invectives.

In the following section, we will have a look at examples of such humorous political statements. The material for this study has been gathered from the humour competition "Silver Mouth" aired by the Polish Radio III Programme from 1992 onwards and hosted by Beata Michniewicz. In this humorous programme, quotations from political debates and other events were displayed in the form of a contest, and the "Silver Mouth" award was offered to the funniest of the quotations on the basis of audience votes. I will describe the communicative (pragmatic) features of the texts that provoked laughter in some part of the auditorium, whereas others remained observers / commentators:

Biada temu pięknemu i historycznemu miastu Kraków! Biada krakowskiej inteligencji, jeśli w Sejmie musi ją prezentować poset Jan Rokita.

Woe to the beautiful historical city of Craców! Woe to Craców's intellectual elite, if it must be represented in the Parliament by Jan Rokita! 
This fragment was uttered by a parliament member from the Samoobrona (Self-defence) group commonly criticised for populism, whereas its supporters are characterised as those with a low social status. Humour of this situation is based first of all on contrasting scripts related to the sender and receiver of this statement (a Member of Parliament representing less educated social groups versus "Kraków (pseudo) intellectuals"). This statement also borrows elements from the curses of the mythological figure of Cassandra, using a somewhat archaic literary style resembling the language of the Polish version of the tragedy, written by Jan Kochanowski.

Panowie z PiS-u, naprawdę, nie lękajcie się!

Gentlemen from PiS, really, do not be afraid!

The joke in this statement is understood only when the contextual associations are referred to. The author of the statement turns to fellow parliamentarians from PiS (Law and Justice party) who in their ideological content refer to Christian values. The formula do not be afraid is therefore a clear paraphrase of a quotation taken from the apostolic call of John Paul II, so probably it triggers the following sub-text: "Parliamentarians from PiS, I will speak to you using a religious vernacular as I am unable to convince you with a parliamentary one".

Jestem tylko skromnym prawnikiem prezydenta [Wałęsy].

I am only a modest lawyer of President Wałęsa.

(meaning 'I am not a great man / big fish')

This fragment includes elements of false modesty which became a source for humour. It was uttered by professor Lech Falandysz, who was one of the most important originators of Polish legislation and legislative reforms in the early period of regained democracy (1990s). Those who criticised him, blamed him for subordinating law to political aims and the derivate falandyzacja describing analoguous behaviour of governing politicians became an entrenched idiom. Probably the audience's ability to decode ironical, false modesty included in that self-presentation was a source of laughter.

Nie można mieć pretensji do stońca, że się kręci wokót Ziemi.

You cannot blame the Sun for revolving around the Earth.

In the abovementioned statement by Lech Wałęsa two meanings collide: it is, on the one hand, an educational and directive comment referring to a simple and colloquial image of the world, and on the other, a logical mistake which provides a source for humour. 
Członek - to brzmi dumnie! (versus Człowiek - to brzmi dumnie!)

A member - it sounds proud! (versus A man - it sounds proud!)

Awkwardness of this slip of the tongue (based on metathesis and homonymy) probably evokes frivolous connotations in the auditorium. Instead of a relevant and serious figure of speech, sexual meaning appeared in the statement introducing a taboo topic in the area of official communication.

Na pytanie udzielone Super Expressowi powiedziat pan: "Wy ze mnie tu alfy i omegi nie róbcie. Ja znam tylko konkrety ogólne!” [...] Będę gtosowat za tym, żeby przyznano panu "Srebrne usta".

You have answered the question of a Super Express journalist like this: "Do not try to make me the alpha and omega. I only know general specific facts!" [...] So I will vote for you to win the "Silver Mouth" award.

Here again, the verbal joke included in this parliamentary discussion should be read at a metacommunicative level. Its author pointed at a figure of speech awkwardly used by a fellow debater and did it in a derisive way; moreover, he assessed it as an unserious statement of low value which should be ridiculed in a satirical media programme.

The examples of slips of the tongue, not carefully premeditated statements and gaffes presented above can be regarded as verbal humour embedded in certain situations, based on the element of surprise when the statements contradicted the audience's stylistic and pragmatic expectations. In other words, comic mental construction based on incongruence was used, which is defined as "inconsistency between something that we expect and something that appears in reality" (Kucharski 2009: 12). Usually the process of reading the text in a non-bona fide mode is explained by the fact that jokes evoke opposed scripts, i.e. scripts that are mutually exclusive in terms of content, antonymic meanings or indications of the intention of speech (theory of Victor Raskin and Salvatore Attardo, quoted by Lew 2000 and others), e.g. when:

1. the receiver interprets the statement in away that is contadictory to the sender's communicative intentions;

2. the form and language of a statement are in discordance with the style or genre required in this particular situation;

3. linguistic devices are so ambiguous that they evoke allusions to other communicative scripts.

It is difficult to mention all linguistic sources and devices active in situationoriented humour in one article. Broadly speaking, they cover the following: 
- language and logical mistakes, slips of the tongue, and self-corrections that may be a source of criticism (derision) aimed at a target or his/her thoughts:

Żadne krzyki i płacze nas nie przekonaja, że biate jest biate, a czarne jest czarne

Neither shouting nor crying will convince us that white is white and black is black

Wiele wskazuje na to, że wrócimy z Kopenhagi na tarczy...y..., nie na tarczy, a z tarczq - przepraszam... odpukać! ... Straszne rzeczy!

Numerous indicators show that we will return from Copenhagen on our shields ...err... not on our shields, but with our shields - I'm sorry ... touch wood! ... Horrendous prospect!

- semantic contradictions based on the mechanism of homonymy, polysemy, and metonymy:

Oświadczam, że nigdy nie byłam księdzem

I hereby declare that I have never been a priest (a female Member of Parliament famous for her cutting remarks; here answering back to those members of parliament who accused her of ignorance about churchrelated problems)

Ja zdaję sobie $z$ tego sprawę, że muszę być $i$ caty czas będę, miẹdzy mtotem a kowadtem, ale już lepiej być między mtotem a kowadtem niż między mtotem a sierpem

I realise that I must be and I will be all the time between the hammer and the anvil but it's better to be between the hammer and the anvil than between the hammer and the sickle (funny contamination of phraseological components with lexical metonymy related to the symbols of the USSR, see Piekot 2012)

- contaminations of different incompatible stylistic devices (including colloquial elements mixed into official style):

Ja już nie szukam pieniędzy za ksiązki, bo te catkowicie udupitem $w$ sprawach społecznych ...

I'm not looking for money for the books any more as I have totally fucked it up in social matters ... 
Odczuwam nieodparta potrzebę, jak patrzę na ten uśmiech $i$ na to spojrzenie $w$ bezkresna dal bezrefleksyjnie utkwione, żeby zadedykować panu premierowi refren z pewnej kabaretowej piosenki: "Co by tu jeszcze spieprzyć, panowie, co by tu jeszcze spieprzyć?”

I still feel the need ... when I look at this smile... and at this gaze into endless space with no self-reflexion... the need to dedicate a chorus from one cabaret song to our Prime Minister: "What else can we screw up, gentlemen, what else can we screw up?"

- inappropriately introduced stylisation (e.g. figures of speech selected from a discourse other than the discourse of politics);

Gratuluje premierze i szczęść Boże na dalsza drogę rzadzenia!

Congratulations, Mister Prime Minister and God Bless You for your continuous government! (wish-related formula taken from the religious idiom as an allusion to a politician representing a political party relying on Christian values)

- allusions to people and events from the sphere of politics:

Przybytem tutaj, aby z gtębokim bólem poinformować Państwa, że postowie Jacek Kurski i Arkadiusz Mularczyk to moje wielkie porażki pedagogiczne. I have come here in order to inform you with a heavy heart that Members of our Parliament Jacek Kurski and Arkadiusz Mularczyk are my two pedagogical failures.

- too emotional (exaggerated) statements / figures of speech:

Idac torem logicznym wtasnego rozumowania: nie mam pytań ...

Following the logical path of my reasoning: I have no more questions ...

- apostrophes directed at debaters - disclosing contradiction between the quasi-polite form and the intention to offend (derision, public reviling of the target):

Pani poset - proszę mi wybaczyć, ale obawiam się, że Pani owies uderzyt do gtowy ...

Madam MP ... - please forgive me but I'm afraid that you have eaten too much oats ... [A reference to the public pronouncement of the MP in question that she likes sex just as much as a horse likes oats fodder.] 
Mam dwa pytania. Jedno pytanie do pana premiera $i$ z cała powaga proszę potraktować to pytanie. Panie premierze, mam wrażenie, i to nie tylko ja mam wrażenie $w$ Polsce, że często pan stoi $w$ rozkroku.

I have two questions. One question to our Prime Minister and please treat it seriously. Mr Prime Minister, I have an impression, and I'm not the only one in Poland to have this impression, that you too often stand astride.

- Modifications (derivations) of well known metaphorical, humorous sayings, comparisons and phrasemes:

Kura najpierw jajko zniesie, a dopiero potem gdacze. Nasi polityczni przeciwnicy gdacza, nawet kiedy nie potrafia jajka znieść.

A hen first lays an egg and only then it cackles. Our political opponents cackle even if they are unable to lay eggs.

\section{Conclusions}

Formulas described above - as it has previously been mentioned - have a status of "winged words". i.e. they are phrasematic lexical units travelling intertextually as quotations (Chlebda 2005) ${ }^{8}$. The attractiveness of such phrases can be confirmed not only by their large communicative versatility (ability to create new senses in texts, i.e. a high level of intertextuality), but first of all by their ability to connote, on the basis of those statements, new allusions about politics by multiplying their ludic potential in different genres and different types of a discourse sensu largo ${ }^{9}$.

Political texts, both 1) containing an intentional humorous element (wherein a sender talks in order evoke laughter / make somebody laugh / ridicule somebody / something) as well as 2) not containing an intentional humorous element, but which can be read that way (where a sender unintentionally evokes laughter or due to incompetent use of language becomes a target of laughter) are usually publicised by journalists, as they convey a metamessage "Attention! Something is going on!". Thus they express the most important categories of contemporary journalistic spirit: sensationalism, emotionalism, loudness and poetics of infotainment (see Bauer 2000, Godzic 2004). The phrases are popularised as lexical (derivative) units of media discourse and have become idioms in the current

8 Compare to comments by Brzozowska (2009a: 163): "Some elements of jokes are to a large extent susceptible to "becoming winged", and in this modified form they often appear in press publications".

9 The phenomena were discussed in Poprawa 2010. 
colloquial language or elements of other, not necessarily humorous, texts. The ritual of repeating those funny statements is best confirmed by the popularity of entertainment programmes (such as the "Silver Mouth" radio broadcast) in which listeners or viewers choose the funniest statement.

Numerous statements of this type give rise to new series or collections of jokes (for example, there is a large Internet collection of verbal and non-verbal quotes from those politicians who promoted the idea of the so called Fourth Republic of Poland), whereas others remain unique political invectives.

The textual origins and fate of those statements (political "winged words") are illustrated in Figure 1 below:

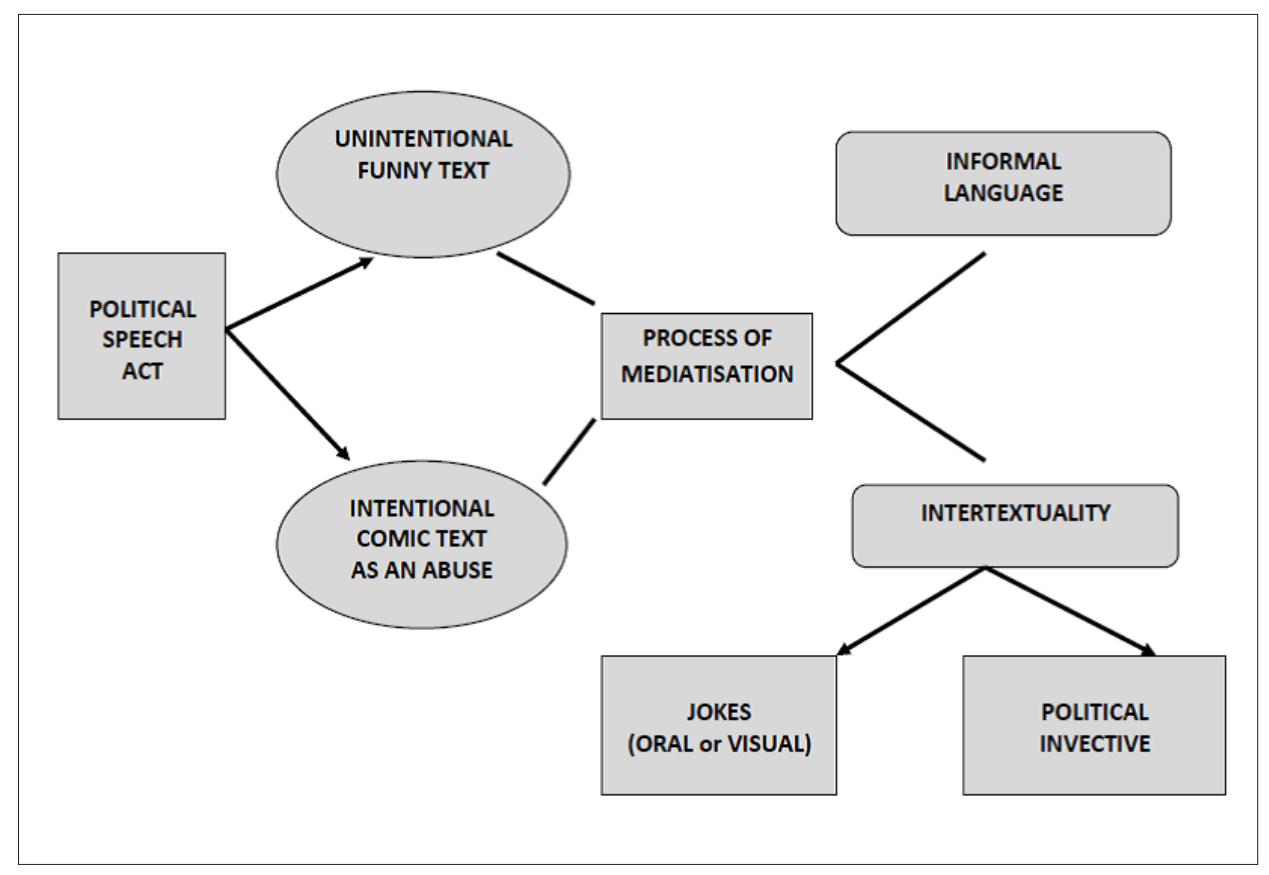

Figure 1. The breakdown of funny political winged words. 
It seems that contemporary public discourse would be incomplete without funny sayings, irrespective of the fact that their form does not always reflect the seriousness of described issues. Although their form offends and they violate communicative norms at the level of language-stylistic performance or etiquette, they may perform several important functions in numerous communicative areas, for example:

- They may become key-words (discursive symbols) used by various speech communities as indicators of their ideological identity (e.g. the phrase mohair coalition / mohair - read by some language users as a humorous pun, whereas by their opponents as a "label" for supporters of conservative groups and the community created around Tadeusz Rydzyk's broadcasting station);

- They may be paraphrased by journalists (or anonymous language users) in order to perform political satire, make up headlines, create content for entertainment programmes designed as infotainment (e.g. presentations of humorous slips of the tongue of politicians in a TVN channel programme entitled Szkło kontaktowe, see Chłopicki 2009);

- They may acquire stable meanings a) in other discourses (e.g. quotations / metonymies used in texts from (popular) culture that contain references to politics and political power struggle (cf. Polish translation of films such as Shrek or Asterix)); b) in contemporary colloquial language (e.g. zdrowie wasze $w$ gardta nasze; plusy dodatnie i plusy ujemne; mordo ty moja!; 'To your health through my throat'; 'positive and negative pluses'; 'The sweet phiz of yours!'); c) sometimes even in the legal and political terminology (e.g. falandyzacja ('falandisation'), gruba kreska ('thick dividing line'), the latter referring to drawing a line between communism and non-communism).

\section{References}

Anusiewicz, Janusz \& Siciński, Bogdan (eds.) 1994. Język a kultura t. 11. Język polityki a wspótczesna kultura polityczna. [Language and Culture Vol. 11. Language of policy and contemporary political culture.] Wrocław: Wydawnictwo Uniwersytetu Wrocławskiego.

Baran, Anneli 2012. Visual humour on the Internet. In: L. Laineste \& D. Brzozowska \& W. Chłopicki (eds). Estonia and Poland. Creativity and tradition in cultural communication, Vol. 1. Tartu: ELM Scholarly Press, pp. 171-186. 
Bauer, Zbigniew 2010. Dziennikarstwo wobec nowych mediów. Historia, teoria, praktyka. [Journalism in the new media. History, theory, practice.] Kraków: Universitas.

Bralczyk, Jerzy 2001. O języku polskiej propagandy partyjnopaństwowej lat siedemdziesiatych $i$ osiemdziesiatych. [The language of policy and party propaganda in the period of the 1970s and 80s.] Warszawa: TRIO.

Bralczyk, Jerzy \& Mosiołek-Kłosińska, Katarzyna (eds.) 2001. Zmiany w publicznych zwyczajach językowych. [Changes in linguistic behaviour.] Warszawa: Rada Języka Polskiego PAN.

Brzozowska, Dorota 2009a. Polish jokelore in the period of transition. In: A. Krikmann \& L. Laineste (eds.). Permitted laughter. Socialist, post-socialist and never-socialist humour. Tartu: ELM Scholary Press, pp. 127-170.

Brzozowska, Dorota 2009b. Polski dowcip etniczny. [Polish ethnic jokes.] Opole: Wydawnictwo Uniwersytetu Opolskiego.

Brzozowska, Dorota 2009c. Polski dyskurs ludyczny i jego międzynarodowe konteksty. [Polish ludic discourse vocabulary and its cultural contexts.] Tekst $i$ dyskurs. Text und diskurs, Vol. 2, pp. 149-162.

Chlebda, Wojciech 2005. Szkice o skrzydlatych stowach. Interpretacje lingwistyczne. [Sketches about winged words. Linguistic interpretations.] Opole: Wydawnictwo Uniwersytetu Opolskiego.

Chłopicki, Władysław 2009. The "Szkło kontaktowe" show - A return to the old rationality? In: A. Krikmann \& L. Laineste (eds.) Permitted laughter. Socialist, post-socialist and never-socialist humour. Tartu: ELM Scholary Press, pp. 171-184.

Chłopicki, Władysław 2012. Stand-up tragedy in Poland? In: L. Laineste \& D. Brzozowska \& W. Chłopicki (eds.) Estonia and Poland. Creativity and tradition in cultural communication, Vol. 1. Tartu: ELM Scholarly Press, pp. 91-110.

Dawidziak-Kładoczna, Małgorzata 2006. "Cherlacy z sercem oziębłym”. O języku pism i mów Józefa Piłsudkiego. [On the public speaches of Józef Piłsudski.] Łask: Leksem.

Davies, Christie 2009. Post-socialist, socialist and never-socialis jokes and humour: continuities and contrasts. In: A. Krikmann \& L. Laineste (eds.) Permitted laughter. Socialist, post-socialist and never-socialist humour. Tartu: ELM Scholary Press, pp. 17-40.

Dytman-Stasieńko, Agnieszka 2006. Święto zawłaszczonych znaczeń. 1 Maja w PRL. Ideologia. Rytuat. Język. [Meanings of a public holiday. May 1st in PRL. Ideology, ritual and language.] Wrocław: Wydawnictwo Naukowe DSWE TWP.

Głowiński, Michał 1992. Nowomowa po polsku. [New-speak in Polish.] Warszawa: Wydawnictwo PEN.

Godzic, Wiesław 2004. Telewizja i jej gatunki po "Wielkim Bracie". [Television and its genres after "Big Brother".] Kraków: Universitas.

Habrajska, Grażyna 1994. Wykorzystywanie ironii do walki politycznej. [The use of irony in political struggle.] In: J. Anusiewicz \& B. Siciński (eds.) Język a kultura t. 11. Język 
polityki a wspótczesna kultura polityczna. [Language and Culture, Vol. 11. Language of policy and contemporary political culture.] Wrocław: Wydawnictwo Uniwersytetu Wrocławskiego, pp. 57-68.

Kamińska-Szmaj, Irena 2001. Stowa na wolności. Język polityki po 1989 roku. [Words at large. The language of politics after 1989.] Wrocław: Europa.

Kamińska-Szmaj, Irena 2007. Agresja językowa w życiu publicznym. Leksykon inwektyw politycznych 1918-2000. [Linguistic aggression in public sphere. The thesaurus of political invectives 1918 - 2000.] Wrocław: Wydawnictwo Uniwersytetu Wrocławskiego.

Kita, Małgorzata 2000. O “złotych myślach” osób publicznych. [“Golden sayings” of public person.] In: D. Brzozowska \& S. Gajda (eds.) Świat humoru. [The world of humour.] Opole: Wydawnictwo Uniwersytetu Opolskiego, pp. 261-270.

Kloch, Zbigniew 2006. Odmiany dyskursu. Semiotyka życia publicznego w Polsce po 1989 roku. [Varieties of discourse. Semiotics of public life in Poland after 1989.] Wrocław: Wydawnictwo Uniwersytetu Wrocławskiego.

Korolko, Mirosław 1996. Sztuka retoryki. [Art of rhetoric.] Warszawa: PWN.

Krikmann, Arvo 2012. Estonian three nation jokes (1964-2012). In: L. Laineste \& D. Brzozowska \& W. Chłopicki (eds.) Estonia and Poland. Creativity and tradition in cultural communication, Vol. 1. Tartu: ELM Scholarly Press, pp. 7-20.

Kucharski, Andrzej 2009. Struktura i treść jako wyznaczniki komizmu tekstów humorystycznych. [Structure and content as markers of the comic in jokes.] Lublin: Wydawnictwo UMCS.

Kudra, Barabara 2001. Kreatywność leksykalna w dyskursie politycznym polskiej prasy lat osiemdziesiątych i dziewięćdziesiatych. [Lexical creativity in the politic discourse of Polish Press in 1980s and 90s.] Łódź: Wydawnictwo Uniwersytetu Łódzkiego.

Lew, Robert 2000. Dowcip językowy w świetle najnowszych językoznawczych teorii humoru. [Jokes in Poland at the turn of the century.] In: D. Brzozowska \& S. Gajda (eds.) Świat humoru. [The world of humour.] Opole: Wydawnictwo Uniwersytetu Opolskiego, pp. 117-125.

Magdoń, Stanisław 1995. Duch zabawy w mediach. [The spirit of fun in media.] Zeszyty Prasoznawcze, Vol. 3-4, pp. 7-16.

Olczyk, Tomasz 2010. Politorozrywka i popperswazja. Reklama telewizyjna w polskich kampaniach wyborczych XXI wieku. [Pop entertainment and pop persuasion. TV advertisement in the election strategies in the 21st century.] Warszawa: Wydawnictwa Akademickie i Profesjonalne.

Ożóg, Kazimierz 2004. Język w stużbie polityki. [Language in the politic's service.] Rzeszów: Wydawnictwo Uniwersytetu Rzeszowskiego.

Piekot, Tomasz 2012. Pictorial representation of idioms in Internet humour. In: L. Laineste \& D. Brzozowska \& W. Chłopicki (eds.) Estonia and Poland. Creativity and tradition in cultural communication, Vol. 1. Tartu: ELM Scholarly Press, pp. 187-204.

Poprawa, Marcin 2009. Telewizyjne debaty polityków jako przyktad dyskursu publicznego. [TV politics debates as an example of public discourse.] Kraków: Universitas. 
Poprawa, Marcin 2010. Intertekstualność dyskursu publicznego - znak wspólnot komunikacyjnych czy konfliktów. [Intertextuality of public discourse - a sign of communities or conflicts.] In: J. Mazur, A. Małyska \& K. Sobstyl (eds.) Intertekstualność we wspótczesnej komunikacji językowej. [Intertextuality in the contempoprary linguistic communications.] Lublin: Wydawnictwo UMSC, pp. 111-123.

Rebane, Martin 2012. Some aspects of telling political jokes in the Soviet Estonia. In: L. Laineste \& D. Brzozowska \& W. Chłopicki (eds). Estonia and Poland. Creativity and tradition in cultural communication, Vol 1. Tartu: ELM Scholarly Press, pp. 111-116.

Stownik terminów literackich. [The dictionary of literacy terms.] 1998. Janusz Sławiński et al. (eds.). Wrocław: Ossolineum.

Szkudlarek-Śmiechowicz, Ewa 2011. Tekst w radiowej i telewizyjnej debacie politycznej. [Text in the political debate on radio and TV.] Łódź: Wydawnictwo Uniwersytetu Łódzkiego.

Van Dijk, Teun A. (ed.) 2001. Badania nad dyskursem. [Discourse researches.] In: T. A. van Dijk (ed.) Dyskurs jako struktura i proces. [Discourse as a structure and a process.] Grzegorz Grochowski (transl.). Warszawa: PWN, pp. 9-44.

Wojtak, Maria, 2010. Gtosy z teraźniejszości. O języku wspótczesnej prasy polskiej. [Voices of contemporary times. About the language of contemporary Polish press.] Lublin: Wydawnictwo WSPA.

www.ipn.gov.pl, last accessed on 13 June 2012. 